\title{
Corporate Social Irresponsibility (CSI) a Catalyst to the Niger Delta \\ Crisis: The Case of Nigerian Oil Multinational Companies versus the Militants of Niger Delta Region of Nigeria
}

\author{
Olusoji James George \\ Department of Business Administration, University of Lagos \\ Lagos State, Nigeria \\ E-mail: eniolasojigeorge2@yahoo.com \\ Owolabi Lateef Kuye (Corresponding author) \\ Department of Business Administration, University of Lagos \\ Lagos State, Nigeria \\ E-mail: labikuye@yahoo.com \\ Uchechi Chioma Onokala \\ Department of Business Administration, University of Lagos \\ Lagos State, Nigeria \\ E-mail: ucheonokala@yahoo.com
}

Received: December 22, 2012

Accepted: February 14, 2012 Published: April 1, 2012

doi:10.5296/jmr.v4i2.1186

URL: http://dx.doi.org/10.5296/jmr.v4i2.1186

\begin{abstract}
The Niger Delta crisis was as a result of years of neglect of the states that constitute the oil rich Niger Delta States. This study aims to see the contribution of the multinational oil companies towards this unrest. Corporate Social Responsibility (CSR) as a discipline came into business management just recently but has made a lot of impact towards the development of the communities where businesses are located. This study intends to look at how and what have been done and what have been left undone by the Multinational Companies (MNCs) that invariably initiated or contributed to the civil unrest of the Niger Delta (the communities
\end{abstract}




\section{Macrothink}

Journal of Management Research

ISSN 1941-899X

2012, Vol. 4, No. 2

where crude oil is abundantly found). The study employing qualitative and multi-method (secondary and primary sources) concludes that the MNCs have behaved irresponsibly towards the host communities through their philanthropic gestures rather than behaving responsibly by genuinely holding and treating the communities as real stakeholders.

Keywords: Corporate social responsibility, Corporate social irresponsibility, Militants, Nigerian oil multinational companies, Niger delta region of Nigeria 


\section{Introduction}

Since 1951 when Nigeria started the exportation of crude oil it has accounted for $90 \%$ of the total revenue of the country (Friedman, 2006). The country tends to be over-dependent on her capital-intensive oil sector, which supplies $95 \%$ of foreign exchange income and about $80 \%$ of budgetary revenues (CIA, 2010). This has displaced groundnut, cocoa beans and other agricultural products which were the mainstay of the economy of the country in the 1950 and 1960's (Frynas, 1999). Crude oil is found abundantly in the following states of the country : Bayelsa, Rivers, Cross Rivers, Delta, Edo, and Ondo; but only Bayelsa, River, Akwa-Ibom, Cross River and Delta States are usually referred to as Niger Delta States (Ikelegbe, 2001). The multinational oil companies operating in the Niger Delta Region were declaring billions of dollars profit year in year out while the communities were left without food, water and shelter due to the constant oil spillage which polluted their rivers and their farmlands; their youths despite their educational attainments were left unemployed (Ikelegbe, 2005). It is often said that "an idle mind is the devil's workshop" and recent experience in Nigeria with youth restiveness in the Niger Delta region is largely the bye-product of unemployment (Owualah and Obokoh, 2008). These frustrations, hunger and anger led to the youths taking up arms, kidnapping the expatriate oil workers a well as destroying crude oil pipelines (Ikelegbe, 2001, 2005; Watts, 2004; Ejobowah, 2000). The actions of the Niger Delta militants (as they are called) threatened the economic survival of the country as over $90 \%$ of the total revenue of the country is from the exportation of crude derived mainly from the Niger Delta States (Ukiwo, 2007;Omege, 2004). The multinational oil companies brought this on themselves and the country through their social irresponsibility.

\subsection{Objectives of the Study}

This work attempts to study social irresponsibility in the Nigerian oil industry by the MNCs. It also seeks to look at how the concept of CSR has been abused by the Multinational oil Companies operating in the Niger Delta Region and how frustration in terms of social and economical development can lead to violence.

\subsection{Research Questions}

In view of the objectives of the study, this paper attempt to find answers to two major questions as follows:

1. How does corporate philanthropy lead to CSR?

2. How does Corporate Social irresponsibility (CSI) of the multinational oil companies in the Niger Delta lead to militancy?

\section{Conceptual/Theoretical Background}

Corporate social responsibility (CSR) is seen in the literature as a way by which businesses put some of their gains to the communities where they are located (Amaeshi, et al, 2006). Failure to do this invariably makes them irresponsible business organisations, which is the theme/focus of this study. Corporate social responsibility according to Carroll (1998), evolved in the 1950s and developed in the 1970s but became well entrenched into the 
business literature in the 1990s. Bowen (1953, p.6) suggested that CSR is the "obligations of businessmen to pursue those policies, to make those decisions, or to follow those lines of action which are desirable in terms of the objectives and values." This study therefore investigates those "lines of action which are desirable," but which the multinational oil companies operating in the Niger Delta have deliberately ignored; this is what made them to be socially irresponsible. There is no doubt about the fact that business organisations are trying everything possible to balance the conflict of demands from communities, governments, pressure groups and other stakeholders about the role business organisations should play in the economic development of the country as a whole, environmental improvement as well as social development of the communities where they operate (Leonard, 2003).

This thesis is grounded on the following CSR theories: Freeman's (1984, 1999) Corporate stakeholding and stakeholder salience, Dore's (2000) stakeholder oriented and liberal market economies (LMEs). The thesis also looks at the various theories on imperialism which includes: conservative theory of imperialism championed by Kidd (1894), Pearson (1897), Steeley (1906) and Bagehot (1906); liberal theory of imperialism by Mill (1859), Hobson (1902), Angell (1910, 1913), Milner (1906, 1912) and Marxist theory of imperialism championed by Marx (1867, 1978), Lenin (1917) and Luxemburg (1951); political theory of imperialism postulated by Morgenthau (1973) and Cohen (1973); dependency theory of imperialism championed Baran (1957, 1966), Rodney (1972), Amin (1976) and Frank (1978). Other theories will include: corporate governance (especially the legal protection of investors theory by Jensen and Meckling (1976) and stakeholder theory.

\subsection{Freeman’s $(1984,1999)$ Corporate Stakeholding and Stakeholder Salience}

According to Freeman (1984, p.246) stakeholders are "those groups and individuals who can affect, or are affected by the achievement of an organisation's purpose.” These groups and individuals include shareholders, employees, suppliers, government, competitors, local communities and the environment. In this thesis these groups and individuals are: the Federal Government of Nigerian, all the communities in the Niger Delta areas and their environment will be conceptualized as their farm lands and their rivers where they fish which unfortunately have now been destroyed through the oil spillage. Freeman (1999, p. 234) suggested that "if organizations want to be effective they will pay attention to all and only those relationships that can affect or be affected by the achievements of the organization's purposes." This is to say that it is very important for organizations (in this study, Shell and AGIP) to pay attention to the salient stakeholders (in this study, the Niger Delta people). Dore $(2000)$ while agreeing with Freeman $(1984,1999)$ suggested that business organizations must be stakeholder oriented.

\subsection{Conservative Theory of Imperialism}

Theories in this school of thought which includes Kidd (1894), Pearson (1897), Steeley (1906) and Bagehot (1906) suggested that imperialism is necessary in order to preserve social order in the more developed countries (in this study the host countries of Shell and AGIP). The people in these developing countries (in this study Nigeria) are seen to be very inferior and do 
not deserve to be treated better. This makes the multinational companies who in most cases are from these developed countries not to take CSR strongly as they would have if they were operating in developed countries. For example the British owned BP was made to pay dearly for the oil spillage in the American Gulf States of 22/05/2010 (CNN news 2/06/2010; The Huffington Post 21/03/2011). Shell (Anglo Dutch owned) on the other has severally ignored the cries to clear its oil spillage in various communities in the Niger Delta Region of Nigeria (Okonta, 2003; Ikelegbe, 2001).

\subsection{Liberal Theory of Imperialism}

Liberal theory of imperialism championed by Mill (1859), Hobson (1902), Angell (1910, 1913), Milner (1906, 1912) argued that imperialism is a policy of choice and not a result of capitalism. They went further to suggest that the economic forces of overproduction which is one of the consequence of industrialisation in the developed countries and the under consumption resulted into imperialism. Invariably, the economic forces of over-production and under-consumption brought about a complex chain of events that are responsible for capital exports to economically under developed countries of Africa (including Nigeria), Asia and the Americas. These are natural consequences of economic forces that can not be stopped by 'civilising' the overseas colonies.

This paper argues that the multinational oil companies operating in the Niger Delta especially are still carrying the imperialist mentality with them; the issue of CSR is therefore not taken seriously as it should have been. For example, the recent oil spillage that occurred in the gulf state of the USA was given a wide publicity and BP (British owned MNC) was made to pay a huge sum of money (\$284 million to the people who were directly affected and the Senate passed a resolution that dividend should not be declared for some years) (CNN News 28/07/2010; The Daily Telegraph Australia, 28/07/2010). In the Niger Delta of Nigeria, this is more like a daily occurrence. In the recent case of Shell $v$ The Ogonis (a community in the Niger Delta), Shell; polluted their farm lands through the oil spillage. The Leader of the community, Ken Saro Wiwa complained. The Federal Government of Nigeria, acting on ‘instructions' from Shell killed Ken Saro Wiwa in 1995. Only recently 11/06/09, the Ogoni people went to an America court (as Justice could not be done in Nigeria under the then Abacha Military Government), Shell paid \$15.5 million as out of court settlement to the Ogoni's (Pambazuka News, 11/06/2009). This is an indictment on Shell and we therefore conclude that the MNC has behaved corporately irresponsibly and that this is imperialism at its best which is one of the areas that will be looked into in this thesis.

\subsection{The Marxist Theory of Imperialism}

The Marxist (1867 \& 1978) theorists believe that the capitalists were compelled to turn to the under developed countries (in this study Nigeria) in order that they can establish new markets so as to accumulate more profit. The Marxists observe that the exported surplus capital by the capitalists was invested in the under developed countries (in this study, Nigeria) not according to the needs of these countries and their people, but according to the interests of the capitalist industrial countries, in most cases represented by their multi-national companies (MNC), in this study Shell and AGIP. 
Most of these Marxists have the opinion that before capitalism can survive it must invade the non-capitalist countries and exploit the peoples (the people of the Niger Delta, in this study) and their resources (in this study, Crude Oil). The people of these communities are also exploited as cheap labour and their resources (in this study, Crude Oil) are taken away from them without much given back to them especially in the form of CSA.

\subsection{The Legal Protection of Investor'S Theory by Jensen and Meckling (1976)}

The investors (in this study, Shell and AGIP) are usually protected by the Legal System. This may come in the form of contract laws, which are bound to be respected. The investors are guaranteed security of their investments and in most cases allowed to repatriate their profits. These are recognised and protected both by local and international laws without which no foreign investment could be attracted. The implication of this is that the investors will do everything possible to make profit as the more profit that is made, the more returns for the owners of the capital. This might be done without any due regard for the CSR or might even be against the interest of the local communities and their environment (through the spillage of oil in their waters and their farm lands, which in turn affects their livelihood).

\section{Method \& Methodology}

This study employs a multi method, qualitative approach using case study methodology, secondary and primary sources data collection following the traditions of Denzin and Lincoln (1994). This is because of three main reasons: The first is to guarantee to a large extent validity and reliability since the weakness of one method could be the strength of another method; secondly, each of the methods is expected to bring in different insight which will result into a richer outcome and lastly, one method is expected to lead to another sequentially and this will make the findings more robust (Whitfield and Strauss 1998). The data analysis was done through narrative analysis following the traditions of George (2011); Cortazzi (1993; 2008). The methodology is therefore a mixture of secondary sources and primary sources.

\subsection{Secondary Sources of Data Collection}

This study employs secondary sources of data collection by going into archives to dig out the history of crude oil in Nigeria, the amount of revenue derived by the Federal Government, the amounts that have been allocated to the Niger-Delta States in the last 25 years. The yearly statement of accounts of Shell and AGIP are also be revealed in order to be able to estimate their yearly profit, the taxes paid to the Federal Government of Nigeria and the amount of resources spent on the Niger Delta communities. The major benefit of secondary sources of data collection is the fact that it is less expensive and easily available (Zikmund, 1984).

\subsection{Primary Sources of Data Collection}

The primary sources of data were through oral interview following the traditions of Bingham and Moore (1959). The interview technique was semi-structured interview. This is to allow for the respondents to speak out. It has also been discovered that if all the respondent does is to speak, they are likely to co-operate. The face to face interview will be done in English 
Language and 'Pidgin English'. 'Pidgin English' originated from the Niger Delta region as a way of communicating with the early colonizers. It is a mixture of the Nigerian native languages with the original English language (Uzukwu, 1997).

\section{Research Findings and Interpretations of Findings}

We dey here one day and the Oyibo people come dey ask for Ovie compound, next thing wey we see some weeks later na 'tear rubber' for the Ovie ( a villager in pidgin English)

Translation in English Language: We were here one day, when some white men came and asked for the house of the village head, weeks later we saw a brand new car in the house of the village head.

Me I no go forgive these oyibo's o; my great grand father na fisherman my father na fisherman; now me no fit fish not to come talk of my pickin. Se all the fish dem do drink oil finish dem don die ( a fisher man in Pidgin English)

Translation in English Language: I cannot forgive the English people (the Oil MNC's); my great grandfather was a renowned fisher-man same with my father but I cannot; not to talk of handling over to my children because all the fishes have been killed by the oil spillage.

We must to fight this fight to finish o, see people for North them dey get fuel so thee they fit dey use am bath but see we no job nothing we just dey why make we no kuku fight and die, we pickin no go suffer and them go say se we be hero o. Them no fit do anything to us this no be Saro Wiwa period na democracy we dey so my friend na fight to finish o ( a militant)

Translation in English Language: We must see this struggle to its logical conclusion. Look at the people in the Northern part of the country; they always have fuel all year round. We do not have job then why not fight and die so that our children will not suffer as we are now suffering and they we regard us as heroes. Please remember this is not a military regime when Saro Wiwa was killed, we are now in the civilian dispensation.

We have tried our best for these 'rebels', we build schools for their children, feed the children, and buy uniforms for them. We tar their roads and even give their Chief's brand new cars what else do they want us to do. We give them electricity light without them paying. Let them go to Lagos and see how NEPA is dealing with you people. They are just trouble makers and not grateful. Afterall we pay taxes to the Federal Government, the State Government and the Local Governments ( A Senior Manager in one of the Oil MNC's).

\subsection{Narratives}

From the above it is obvious that the philanthropic theory is in play; the MNC's believe that after paying tax they should not be made to contribute to the environment. They also 'bride' their ways with the village heads and therefore disconnected from the realities. The militants have made up their minds to rather die, which is a very dangerous situation. The militants will not give up, so the ball is now in the courts of the Federal Government of Nigeria and the MNC's. 


\section{Conclusion, Recommendations and Direction for Further Studies}

There is a systematic corrupt practices perpetuated by many Nigerian government officials in collaboration with the MN oil companies. There is also a lot of corruption involving the community leaders in Niger Delta which ended up undermining the social and economic development of the area. The MNCs especially in the oil industries in Nigeria are operating the concept of corporate philanthropy instead of corporate social responsibility and this invariably makes them to become corporate social irresponsible organisations. Some of their activities have created unemployment in the Niger Delta region. It is probably for this reason that the increased restiveness among the youths of the region, most of whom are jobless, poses serious dangers for the nation's social as well as economic stability (Owualah and Obokoh, 2008). The cumulative effect of all the above was what led to the militancy of the youth (for example MEND, Asawana boys, and Egbesu boys) who had to result to taking up of arms and kidnapping expatriate oil workers for ransom as was done by their forefathers in the 1800s over palm oil (George, 2011).

The solution to the above is to provide full employment to the numerous unemployed youths of the Niger Delta. Principally, the time is now ripe for profit sharing rather that corporate philanthropy; it is proposed that even if it is $10 \%$ of the yearly profit of the MN oil companies operating in the Niger Delta Region should go directly to the communities where the MN oil companies operate. This is apart from the taxes and royalties paid to the Federal and state governments of Nigeria. The effect of this is that the communities will become real and genuine stakeholders in the oil business rather than the philanthropic gestures of buying tables and chairs and providing free meals to the students in the Niger Delta. The present situation of establishing petroleum refineries in the North ( for example Kaduna) with crude oil coming from the Niger Delta over $5,000 \mathrm{~km}$ away does not make any economical sense. Petroleum refineries should be located near to the sources of raw materials (crude oil).

There is a need for further studies to be carried out as to how to make the Amananoweis (chiefs/ head of the community) to shun corruption and think about what will benefit the community in general rather than being satisfied with eating the crumbs that drop from the table of the multinational oil companies. There is also a need to find a way of compelling the youths to get educated, rather than turning into militants and kidnapping expatriates and even some senior Nigerian managers. There is a need for further researches on the issue of resource control and the need for the practice of proper federalism as is being practiced in the USA. Each state of the federation could now manage the resources in their states and royalties will be paid to the Federal Government. Researchers in the CSR discipline should recommend the barest minimum of the profits of firm that should be spent on CSR project. This will make it easier to categorise MNC's into corporate social responsible MNC's or corporate socially irresponsible MNC's. Finally, as the issue of oil spillage knows no boundary, the MN oil companies some concentrate their researches on how to bring it to the barest minimum at least and how it could be cleared in good time with minimum damage to the environment. 


\section{Limitations}

Secondary data were employed in this study. Secondary data are data collected and recorded by someone else before the current study and the purpose is for other needs not for the current research (Harris 2001). Most secondary data are usually historical and do not necessitate the access to respondents or subjects (Ember and Levinson 1991). The major disadvantage is in the fact that care should be taken when using secondary sources because the data are not collected with the present study in mind. It might therefore not meet the present researcher's needs (Cowton, 1998). However, all efforts have been made to remove bias as humanly as possible. Also, sufficient resources and time would have enabled the researcher to extend the study to cover all the multinational oil companies in the area, which will enable one to decipher what companies have been more responsible or irresponsible.

\section{References}

Amaeshi, K.M., Adi, B.C., Ogbechie, C., \& Amao, O.O. (2006). Corporate Social Resposibility in Nigeria: Western Mimicry or Indigenous Influences? Journal of Corporate Citizenship, 24: 83-99. DOI:10.2139/ssrn.896500. http://dx.doi.org/10.2139/ssrn.896500

Angell, N. (1910/1913). The Great Illusion: A Study of the Military Power to National Advantage, London: G.P. Putnam’s Sons.

Bagehot, W. (1906). Physics and Politics. New York: Appleton

Baran, P. (1957). The Political Economy of Growth New York: Monthly Review Press

Baran, P. (1966). Monopoly Capital: An Essay on the American Economic and Social Order. New York: Monthly Review Press.

Bingham and Moore. (1959). How to interview. New York: Harper Collins.

Bowen, H.R. (1953) .Social Responsibilities of the Businessman. New York: Harper \& Row.

Carrol, A.B. (1999). Corporate Social Responsibility’. Business and Society, 38(3): 268-295.

Central Intelligence Agency. (2010). The World Factbook. Available at: https://www.cia.gov/library/publications/the-world-factbook/geos/ni.html. Accessed 5 August 2010.

Cohen, B.J. (1973). The Question of Imperialism: The Political Economy of Dominance and Dependence. New York: Basic Books.

Cortazzi, M. (1993). Narrative Analysis. New York: Routledge.

Cortazzi, M. (2008). Narrative Analysis. Language Teaching, (27):57-100.

Cowton, C.J. (1998). The Use of Secondary Data in Business Ethics'. Journal of Business Ethics, 17(4): 423-434. http://dx.doi.org/10.1023/A:1005730825103

Denzin, N.K, \& Lincoln, Y.S. (1994) Handbook of Qualitative Research. Thousand Oaks. London, New Delhi: Sage Publication. 
Dore, R. (2000). Stock Market Capitalism: Welfare Capitalism, Japan and Germany versus the Anglo-Saxons. Oxford: Oxford University Press.

Ejobowah, J. B. (2000). Who Owns the Oil? The Politics of Ethnicity in the Niger Delta of Nigeria. Africa Today, 47(1): 29-47. http://dx.doi.org/10.1353/at.2000.0011

Ember, C.R., \& Levinson, D. (1991). The Substantive Contributions of Worldwide Cross-cultural Studies Using Secondary Data. Behaviour Science Research, 25(1-4): 79-140.

Frank, A.G. (1978). Dependent Accumulation and Underdevelopment. London: Macmillan

Freeman, R. E. (1984). Strategic management: A stakeholder approach. Boston: Pitman

Freeman, R. E. (1999). Response: Divergent stakeholder theory. Academy of Management Review, 24(2):2 33-236.

Friedman, T.L. (2006). The First Law of Petropolitics. Foreign Policy, 154:28-39.

George, O.J. (2011). Impact of Culture on The Transfer of Management Practices in Former British Colonies: A Comparative Case Study of Cadbury (Nigeria) Plc and Cadbury Worldwide. New York: Xlibris Corporation.

Frynans, J.G. (2000). Oil in Nigeria: Conflict and Litigation Between Oil Companies and Village Communities. NJ: Transaction Publishers.

Harris, H. (2001). Content Analysis of Secondary Data: A Study of Courage in Managerial Decision Making. Journal of Business Ethics, 34(3-4): 191-208. http://dx.doi.org/10.1023/A:1012534014727

Hobson, J.A. (1902/1968). Imperialism: A Study. London: George Allen \& Unwin.

Jensen, M., \& Meckling, W. (1976). Theory of the Firm: managerial behaviour, agency costs, and ownership structure. Journal of Financial Economics 3 (4): 305-360. http://dx.doi.org/10.1016/0304-405X(76)90026-X

Ikelegbe, A. (2001). Civil Society, Oil and Conflict in the Niger Delta Region of Nigeria: Ramifications of Civil Society for a Regional Resource Struggle. Journal of Modern African Studies, 39(3): 437-469.

Ikelegbe, A. (2005). The Economy of Conflict in the Oil Rich Niger Delta Region of Nigeria. Nordic Journal of African Studies, 14(2): 208-234.

Kenneth, O. (2004). The State, Conflict and Evolving Politics in the Niger Delta Nigeria. Review of African Political Economy, 101: 425-440.

Kidd, B. (1894). Social Evolution. London and New York: Macmillan.

Lenin, V.I. (1917). Imperialism, the Highest Stage of Capitalism in Essential Works of Lenin, ed. Henry M. Christman. New York: Dover. 


\section{Macrothink}

Journal of Management Research

ISSN 1941-899X

2012, Vol. 4, No. 2

Leonard, D. (2003). Corporate Social Responsibility. Journal of Quality Progress . http://charlesrivercentre.com/brochures/CSR-20080421-NC.pdf. Accessed on March 19 2011.

Luxemburg, Rosa. (1913/1968). The Accumulation of Capital. New York: Monthly Review Press.

Marx, K., \& Engels, F. (1978) Ireland and the Irish Question. Moscow: Progress Publishers.

Marx, K. (1869). Outline of a Report on the Irish Question to the Communist Educational Association of German Workers in London, December 16. in idem and Frederick Engels, Ireland and the Irish Question, Progress Publishers: Moscow, 1978, pp.136-149.

Mill, J.S. (1859/1984). A Few Words on Non-Intervention in J.M. Robson (ed.), Collected Works of John Stuart Mill, XXI (Toronto: Toronto University Press), 111-124.

Milner, A. (1906) A Political Ishmaelite. UK: Wolverhampton.

Milner, A. (1912). The Two Nations. London: East London Publishers

Morgenthau, H. J. (1973). Politics Among Nations: The Struggle for Power and Peace, $5^{\text {th }}$ ed., New York: Alfred A. Knopf.

Okonta, I. (2003). Where the Vultures Feast: Human Rights and Oil in the Niger Delta. New York: Blackwell Publisher.

Owualah, S.I., \& Obokoh, L.O. (2008). Tackling Youth Restiveness in the Niger Delta region of Nigeria through Enrepreneurship. Journal of Enterprising Communities, 2(2): 168-179.

Pearson, K. (1897). Socialism and Natural Selection", in The Chances of Death and Other Studies in Evolution. London: Pearson. http://dx.doi.org/10.5962/bhl.title.18666

Seeley, John Robert. (1906). The Expansion of England Leipzig: Velhagen \& Klansing.

Ukiwo, U. (2007). From "Pirates" to "Militant": A Historical Perspective on Anti-State and Anti-Oil Company Mobilization Among the Ijaw of Warri, Western Niger Delta. African Affairs, 106(425): 587-610. http://dx.doi.org/10.1093/afraf/adm057

Uzukwu, E. (1997). Worship as a Body Language. Enugu: Liturgical Press.

Watts, M. (2004). Resource Curse? Governmentality, Oil, Power in the Niger Delta, Nigeria, Geopolitics, 9(1): 50-80. http://dx.doi.org/10.1080/14650040412331307832

Whitfield, K., \& Strauss, G. (1998). Researching the World of Work: Strategies and Methods in Studying industrial Relations. London: ILR Press.

Zikmund, Z. (1984). Symmetry of Domain Pairs and Domain Twins. Journal of Physics, 34(9): 932-949. 